\title{
Lumen
}

Selected Proceedings from the Canadian Society for Eighteenth-Century Studies

\section{Entertainment and Didacticism: Eliza Haywood's The Unequal Conflict and Fatal Fondness}

\section{Holly Luhning}

Volume 29, 2010

URI : https://id.erudit.org/iderudit/1012033ar

DOI : https://doi.org/10.7202/1012033ar

Aller au sommaire du numéro

Éditeur(s)

Canadian Society for Eighteenth-Century Studies / Société canadienne d'étude du dix-huitième siècle

ISSN

1209-3696 (imprimé)

1927-8284 (numérique)

Découvrir la revue

Citer cet article

Luhning, H. (2010). Entertainment and Didacticism: Eliza Haywood's The

Unequal Conflict and Fatal Fondness. Lumen, 29, 161-174.

https://doi.org/10.7202/1012033ar

Copyright (c) Canadian Society for Eighteenth-Century Studies / Sociéte canadienne d'étude du dix-huitième siècle, 2010
Ce document est protégé par la loi sur le droit d'auteur. L'utilisation des services d'Érudit (y compris la reproduction) est assujettie à sa politique d'utilisation que vous pouvez consulter en ligne.

https://apropos.erudit.org/fr/usagers/politique-dutilisation/ 


\section{Entertainment and Didacticism: Eliza Haywood's The Unequal Conflict and Fatal Fondness ${ }^{1}$}

Eliza Haywood produced innovative, socially meritorious, and entertaining literature throughout her career. In particular, her novels often told stories about people who did not always make socially or morally correct choices; their missteps made them interesting and provided the basis for stories that examined what happened when people defied the status quo. Alexander Pettit observes that "[i]nstead of making her characters fit prescribed moral standards of behaviour, Haywood often preferred characters that broke social taboos ${ }^{\prime 2}{ }^{2}$ Haywood's novels investigate how people come to find themselves at the margins of respectable society. Her work considers not only how a character arrived at such a juncture but also questions the fairness of the social limits the characters encounter. Her writing often adheres to social norms on one level while incorporating subversive social criticism on another. Specifically, Haywood's novels often criticize beliefs about gender, class, health, and sexuality while the resolution of her novels reaffirms the strength and influence of these cultural systems. These sorts of contradictions signal cultural anxieties regarding the body, women's sexual agency, class, and wealth; Haywood's writing represents apprehensions and

1 Eliza Haywood, The Unequal Conflict; Or, Nature Triumphant. (London: J. Walthoe, 1725); Fatal Fondness; Or, Love, its own Opposer. Being the Sequel of The Unequal Conflict. (London: J. Walthoe, 1725).

2 Alexander Pettit, "Introduction." Fantomina and Other Works. Ed. Margaret Case Croskery et al. (Peterborough: Broadview, 2004) 16. 
shifting perceptions about social hierarchies and gender roles. Her subject matter is often scandalous and entertaining; at the same time she weaves social criticism throughout her narratives.

Haywood's ability to simultaneously embrace yet critique the social standards of her time allow her to synthesize and expand on specific manifestations of these social apprehensions, particularly in regard to women's social and sexual conduct. The companion novels The Unequal Conflict (1725) and Fatal Fondness (1725) reflect a knowledge of and engagement with several tenets presented in ladies' conduct literature, yet often contest the advice these texts give in regard to achieving the model behaviour these texts promote. In these novels in particular, Haywood creates texts that are both broadly entertaining to readers, yet engaged with an established dialogue about ladies' conduct. Haywood's didacticism is made possible by her texts' ability to entertain; as Kathleen Lubey posits "in order for readers to derive lessons from fictive events, Haywood must present them in the titillating and inflammatory manner in which characters receive them" ${ }^{3}$ In contrast to the dry, moralizing advice or admonitions presented in conduct literature, this combination allows Haywood to embody a socially convincing didacticism in her stories.

\section{Background on the Texts}

Since The Unequal Conflict and Fatal Fondness have not been published in modern editions and have occasioned little to no critical work, I will pause here to provide some context for these novels. The Unequal Conflict is available on the Eighteenth-Century Collections Online database, but Fatal Fondness is not included in the database. The only known existing copy is held at Sir John Soane's Museum Library, a small institution in London. As with much of Haywood's early work, these novels were popular and sold well. According to Patrick Spedding's bibliography of Haywood, The Unequal Conflict went through at least two issues by 1726, the period of one year. ${ }^{4}$ The Unequal Conflict focuses on two heroines: Philenia and Antonia. At the outset of the story, Antonia is in

3 Kathleen Lubey, "Eliza Haywood's Amatory Aesthetic." Eighteenth-Century Studies 39.3 (2006), 309-10.

4 Patrick Spedding, A Bibliography of Eliza Haywood. (London: Pickering and Chatto, 2003). The scarcity of known, surviving copies of Fatal Fondness has made it more challenging to trace accurately its publication history. 
a loveless marriage and she and her husband lead fairly separate lives and engage in extra-marital flirtations. She meets her husband's friend Coeurdemont and falls in love with him; however, the close friendship between Coeurdemont and her husband becomes an obstacle to Antonia's desires to begin an amour with Coeurdemont. Additionally, Coeurdemont begins to court Philenia, a young woman from a respectable, wealthy family. Antonia's husband dies and she becomes free to be involved with Coeurdemont, but in the meantime Coeurdemont has asked Philenia's father for her hand in marriage and her father encourages this match. Antonia develops a friendship with Philenia and tells her father she will try to convince Philenia to accept Coeurdemont's offer, but instead she uses this ruse to visit Philenia frequently and to convince her to meet with her other suitor, Fillamour. Fillamour loves the less-wealthy Philenia but his uncle opposes the match and threatens to withhold Fillamour's fortune if they marry. However, Antonia succeeds in convincing Philenia to rendez-vous with Fillamour; her father discovers the secret meeting and Philenia flees to a bagnio, and then to a country house where she becomes Fillamour's mistress.

Fatal Fondness tells the second half of Antonia and Philenia's stories. Philenia remains in the country as Fillamour's mistress, even though Fillamour capitulates to his uncle's wishes and marries another woman. Fillamour also takes another mistress and increasingly neglects Philenia. A band of rogues kidnaps Philenia and tries to take her to Amsterdam; the boat shipwrecks and she escapes to a fishing village in England where she supports herself by making fishing nets. She believes Fillamour will come to rescue her. Meanwhile, Coeurdemont is involved in a duel in London and is pursued by the authorities. Antonia offers to help Coeurdemont escape on the condition that he marry her. He does and they flee to Amsterdam. While they are waiting to board the boat, they find Philenia in the fishing village. Antonia tells Philenia her father is ill and that he wishes to see her and forgive her trespasses. Philenia rushes back to London but chooses to visit Fillamour instead of her father. Her father dies and Fillamour's jealous mistress stabs Fillamour; stricken with grief, Philenia commits suicide.

\section{Conduct Literature and Novels}

The Unequal Conflict and Fatal Fondness dramatize the restrictive social world in which young upper-class women lived in the eighteenth century, particularly in regard to courtship and marriage. Young women were encouraged to find a suitable husband, but "despite a general eagerness on the part of women to be married, custom demanded that 
they maintain an attitude of indifference or even of aversion" ${ }^{5}$ Conduct manuals of the time expressly stated that not only should women never solicit a man's affection, they should also not reveal that they are interested in a man's attentions:

They ought not to shew at first...Rigour; for that rather chases away than gains a Lover. Nor ought they to yield their Hearts as soon as they are solicited; for that is rather the Effect of a foolish Pity, than of the Merit of their Suitors; and he will not be apt to esteem that much, which costs him so little, and is aquired with so much ease.

It is thus that these ... Fair-ones captivate Hearts by a noble Pride: For in despising Love at the first, they at last triumph with the greater Power. ${ }^{6}$

Women were expected to conceal their amorous interests in order to secure a man's esteem and affections. These novels take place in a world where "cultural codes... assign primary sexual desire and initiation to men"'. ${ }^{7}$ When women break those codes they risk being socially, economically, and emotionally outcast by their families and culture.

In addition to concealing their emotions in regard to their suitors, women were also expected to give their parents and guardians unquestioning love and obedience, and to follow their advice on the matters of marriage and courtship. The economic and legal power a husband possessed over a wife "made the prospect of entering such a state of bondage, and for life, daunting". ${ }^{8}$ Young women were expressly instructed to follow the advice of family and friends in choosing a husband. In John Essex's 1722 ladies' conduct manual, he writes:

Marriage is an Affair of that Consequence in Life, that it is great Imprudence in a young Lady to venture on it, without good Consideration; great Ingratitude to do it, without Advice of Parents, Friends, \&c.

5 E. Brophy, E. Women's Lives and the Eighteenth-Century English Novel. (Tampa: South Florida UP, 1991) 107

6 Anon. The Ladies Library Written by a Lady. Published by Sir Richard Steele. $3^{\text {rd }}$ edition. London: Jacob Tonson, 1722. iii

7 Toni Bowers, The Politics of Motherhood: British Writing and Culture 1680-1760. (Cambridge: Cambridge UP, 1996) 55.

8 Brophy 94

9 Essex, John. The young ladies conduct: or, rules for education, under several heads; with instructions upon dress, both before and after marriage. And advice to young wives. 
Women were supposed not to have the experience, foresight, and social knowledge necessary to choose their own match. Essex again stresses the importance of consulting parents or guardians in arranging a successful marriage:

You are to be intreated, I say, to consult your Parents or Guardians, and be inform'd from them, that in so nice a Conjuncture, in order to have a happy Marriage, Man and Wife should have but one and the same Interest; and to make up this, there must be a suitable Agreement and Harmony in Age, Humour, Education and Religion; nay, even in Families and Fortunes; and when all these concur, we may expect an equal Satisfaction, as a natural result of an equal Match. ${ }^{10}$

Conduct literature extolled the overall importance of a young woman to engage in courtship and entering marriage, yet also emphasized a woman's inability to make good decisions for herself in these areas.

Although Haywood explores and oftentimes confirms some common tenets of conduct literature in The Unequal Conflict and Fatal Fondness, novels and conduct literature were not often perceived of as complimentary reading material for eighteenth-century women. Essex cautions that women are at risk of "trifl[ing] away their Time in an Impertinent Song or Novel; so that often more is lost than gained by this Accomplishment [reading]" ${ }^{11}$ Norma Clarke contextualizes the eighteenth-century attitude toward identifying novel-reading as a negative pursuit:

This model permeated eighteenth-century thinking...It identified the pleasures of study and the delight of unfettered enquiry with a general loosening of restraints. Independence of mind in women signaled the likelihood of disreputable freedoms with the body. ${ }^{12}$

Novels, particularly amatory fiction such as Haywood's, explored the intellectual and physical restrictions of marriage, courtship, and economic and educational disenfranchisement. The stories featured

London, 1722. (Gale Group: Eighteenth Century Collections Online. 7 May 2008 $<$ http://galenet.galegroup.com.cyber.usask.ca/>) 95

$10 \quad$ Essex 97

11 Essex, $x \mathrm{i}$

12 Norma Clarke, The Rise and Fall of the Woman of Letters. (London: Pimlico, 2004) 7 
women who explored their sexuality outside of marriage and who were not always consistently or immediately punished for taking these physical freedoms. Female characters who challenged social order did not always suffer harsh consequences; further, heroines who were punished were often presented as sympathetic characters who possessed positive qualities, yet made some unfortunate life decisions. While these stories did not consistently oppose the status quo, they did not consistently affirm it, either.

Not surprisingly, moralists and conduct writers were concerned about the potential influence of popular novels. Paul Hunter posits that three things "especially concerned them": novels featured heroes and heroines who rose above their social station, novels valued sentiment and feeling over rationality and truth, and they described sexual attraction in romance and courtship. The inclusion of sexual attraction in their depictions of romance threatened to "warm the imagination... [and] overheat the passions". ${ }^{13}$ Novels often investigated the human condition, focused on individuals, and promoted personal agency. Hunter writes that novels represented "new and upsetting values and unpredictable ways of living, thinking and believing". ${ }^{14}$ Characters in novels owned, acted in, and sometimes changed their realities. Also, early novels often focused on themes of decision-making about life issues such as money, inheritances, courtship, and marriage, and the consequences of such decisions. The content of these works contributed to a basic cultural knowledge about one's life; guardians and conduct manuals lost their monopoly on such topics, which, especially in the more rigid social codes of the upper classes, could be very dangerous indeed. Popular novels, such as Haywood's, occupied a position of considerable cultural power in terms of reflecting, challenging, and creating social codes regarding gender roles and women's behaviour.

Despite perceptions that novels undermined the precepts promoted in conduct literature, Haywood's The Unequal Conflict and Fatal Fondness illustrate, reinforce, and expand on many ideas put forth by conduct literature. Haywood's novels rely on and engage with common ideals for women's behaviour. However, instead of parroting the advice from the manuals, Haywood connects the advice to particular situations, motivations, and challenges. Instead of "entreating" the reader

13 J. Paul Hunter, "The Novel and social/cultural history." The Cambridge Companion to The Eighteenth-Century Novel. Ed. John Richetti. (Cambridge: Cambridge UP, 1996) 21 
or her characters to behave in one way or another, Haywood allows her female characters to make many of their own decisions regarding courtship, sexuality, and marriage. While many characters who do not follow prescribed behavioural standards suffer unfortunate events, Haywood's narrator does not often judge or condescend to these characters. Instead, Haywood draws attention to the lack of education and awareness of social systems that lead women to make choices that lead to unfortunate consequences. Also, she highlights the rigid and pervasive systems of gender and class and the narrow set of choices women had within this milieu. Haywood's novels work to illustrate the social mechanisms behind the advice in conduct literature. Instead of "entreating" or "demanding" that young women behave in certain ways, her novels offer to young women a comprehensive view of why it is important to conduct oneself in a particular manner in the context of their current social realities. Unlike Essex's attitude that women are not capable of making wise decisions on their own, Haywood's stories assume that women can look out for their own best interests, once they are educated fully about their social and cultural worlds and their places within those worlds.

Haywood's novels also differ from conduct literature in regard to their attitude toward female emotion and sexuality; while much conduct literature presents emotion and sexual desire as feelings to be overcome or ignored in order to make decisions informed by reason and wisdom, Haywood's work suggests that women can and should acknowledge desire and feeling while they retain the ability to make socially shrewd, active choices. For example, François Fénelon's 1707 conduct manual Instructions for the Education of a Daughter suggests that women consider the following in regard to their conduct:

I had rather persuade you therefore to consider the Excellencey of your Soul; and the Object which is upon you to make it appear worthy of the Rank which you hold in this World; and this is not so easie to be done, except you watch diligently over it, and find a secret Pleasure, in observing that your Soul is still more Noble than your Extraction. ${ }^{15}$

15 François Fénelon, Instructions for the Education of a Daughter, By the Author of Telemachus. To which is added, A Small Tract of Instructions for the Conduct of Young Ladies of the Highest Rank. With Suitable Devotions Annexed. Done into English and Revised by Dr. George Hickes. (London: Jonah Bowyer, 1707) 306. 
This writer suggests that women should be motivated to adhere to strict rules of conduct in order to preserve their noble souls. However, this type of advice does not clearly explain how or against what a woman should watch diligently over their souls. Additionally, while the fate of one's soul is a weighty concern, it is a relatively intangible issue. In contrast, Haywood's novels illustrate the more earthly, corporeal problems that can arise when women make uninformed decisions, such as disownment and disenfranchisement from the family unit, social ostracization, pregnancy, poverty, madness, and death. Novels such as The Unequal Conflict and Fatal Fondness offer specific examples of how and why to behave, and how not to behave, in order to protect oneself from social ruin while under the influence of love. Additionally, Haywood's stories not only illustrate to women how to survive socially while they are in love, but the stories also explore the limited opportunities women have for manipulating their social systems to obtain their romantic goals.

\section{Antonia and Philenia}

Haywood features two heroines in this pair of novels, Philenia and Antonia, whose stories and romances interact a various points; Philenia becomes a victim of her poor judgment and lack of insight, and Antonia effectively manipulates her social systems to obtain what she wants without experiencing repercussions. Haywood's heroines work as role models who dramatize vibrant cautionary tales. Philenia, an intelligent, educated, virtuous, yet socially inexperienced young woman, becomes a victim of Antonia's manipulation, a social outcast, and ultimately a corpse after clumsily transgressing social codes for love. In contrast, Antonia also commits many transgressions, but she is experienced with and aware of the world that she inhabits and she successfully negotiates social codes in order to pursue her beloved. While Philenia engages in an unquestioning participation in a social system that visits serious consequences on transgressors, Antonia engages in what Katherine Kitteredge calls "an act of social negotiation". ${ }^{16}$ Antonia assumes agency within an awareness of restrictive systems that limit her life; ultimately, she succeeds in keeping her motivations private and fulfilling her desires. Meanwhile, Philenia's repeated, seemingly heedless

16 Katherine Kittredge, "Introduction." Lewd and Notorious: Female Transgression in the Eighteenth-Century. Ed. Katherine Kittredge. (Ann Arbor: U of Michigan P, 2003) 13 
attitude toward the consequences of her public transgressions works to marginalize her socially, economically, and emotionally.

For example, one key insight that the narrator and Antonia possess, and which Philenia does not, is a particular understanding of male behaviour; overall, the narrator repeatedly claims that most men have a limited capacity to love, that their feelings are naturally mutable, and that love is only one concern among many in their lives. In The Unequal Conflict, the narrator explains that "though [Fillamour] was posses'd of a much greater share of tenderness for [Philenia] than men are ordinarily capable of feeling... to marry her without a fortune was no way agreeable to his circumstances" (9). Philenia's father recognizes that Fillamour is not a very serious suitor and recommends that she instead marry the worthy Coeurdemont. Here, Haywood fleshes out a probable explanation regarding why, as conduct precepts insist, it is in Philenia's best interests to listen to her father; he has insight into the world and male behaviour and thus is able to foresee the negative consequences of Philenia's infatuation with this unworthy suitor. However, he does not explain his reasons for keeping her from Fillamour, so she does not have the opportunity to learn from this situation.

The narrator repeatedly emphasizes that Fillamour cares for Philenia very much, but also clearly outlines his poor treatment of her; Philenia's lack of knowledge about men and courtship lead her to be repeatedly mollified by Fillamour's lies. For example, Philenia "in some little time receiv'd the shocking and most surprising account, that Fillamour had comply'd with his uncle's desires, and was married to that young lady he had recommended" (61), but Fillamour still convinces her not to return to her father and to instead become his mistress. Eventually, he is distracted by yet another woman, Misemene, and begins an affair with her. By the time Philenia is mistakenly kidnapped, Fillamour "had all the concern that friendship, gratitude, and pity cou'd inspire; but those, alas! are weak and enervate passions, and but feebly influence the breast" (50); he inquires after her, but does not launch a search. Still, Philenia remains faithful to Fillamour. Unlike Antonia, Philenia develops little insight in regard to her suitor's worth; although she is depicted as a very intelligent, capable woman, this lack of understanding limits her abilities to make positive social choices. For example, after Philenia escapes from her kidnappers when their ferry sinks, she makes a life for herself in a local village, making fishing nets to support herself. She

maintained herself in a manner, which, tho' a mean one, might have been comfortable if her untir'd affection for Fillamour had not made her impatient at being oblig'd to continue in a place, where there was no possibility of seeing him. (64) 
Philenia achieves financial independence but sacrifices this lifestyle because of her continued love for the unworthy Fillamour. She returns to London to find him, and this blind affection results in her death. Unlike the narrator and Antonia, she does not consider that Fillamour may have different priorities, and so endangers her own economic and social wellbeing in her pursuit of a relationship with him. Philenia falls, in part, because she does not understand the differences between male and female experiences of and devotion to love.

In contrast to Philenia, Haywood creates the socially savvy Antonia. Antonia conducts a very calculated, tactical campaign to obtain a marriage to Coeurdemont. Although Antonia commits several acts that reflect her questionable moral standards, she is the only female character who obtains her desires at the end. Haywood's narrator presents Antonia's experience and calculated social maneuvering as almost necessary for women to obtain their desires in the context of the extremely limited social roles afforded to women. In addition to using the affair between Fillamour and Philenia to advance her objectives, Antonia bribes a man to marry her maid, Maria, with whom Coeurdemont had had an affair, and to take Maria to America. She hides Coeurdemont from the police after he has injured a man in a duel, but immediately capitalizes on his gratitude and vulnerable position; she offers her assistance only on the condition that he marry her. When Antonia sees Philenia in the fishing village, she tells her that Coeurdemont "married me immediately after our arrival here, and prov'd himself a man of honour, sufficient to justify the passion I have had for him" (79). Antonia's goals are motivated by her passion for Coeurdemont, yet she executes her plans rationally and efficiently. Unlike Philenia, she possesses a comprehensive understanding of her social world and does not lose sight of the idea that although she may be in love with Coeurdemont, this love does not necessarily signify that he is worthy of her devotion, or that such devotion would not harm her, socially and economically.

While Haywood's novels affirm some popular views on female conduct, ${ }^{17}$ they also consistently advocate that young women, in addi-

17 In the past, some scholars constructed a critical narrative regarding Haywood's career that suggested her early works were exclusively amatory, bodice-ripper type works, and that her later works were didactic and moralistic. More recent criticism by scholars such as Paula Backscheider, Juliette Merritt, Catherine Ingrassia, and Kathleen Lubey has rejected this construction of a stark division in the nature of Haywood's writing and has illustrated several commonalities among her diverse and extremely numerous works. I aim to build on this body of criticism and embrace Merritt's assertion that "Haywood studies have arrived at a point at 
tion to looking inward and cultivating virtue within themselves, must also look outward, and familiarize themselves with their social reality. Haywood's narrator teaches women to become aware of themselves as potential agents within their social worlds rather than remain passive vessels inescapably swayed by the effects of passion, or blindly follow conduct regulations because of threats of vague, terrible consequences to themselves and their souls. This pair of novels is significant for how, as well as what, they teach young women about social systems; Haywood consistently rejects the commanding, condescending tone of conduct literature and instead trusts her readers to engage with and understand the nuances of the social world she discusses in these novels. Through this engagement with her readers, she creates an entertaining, titillating, didactic vehicle.

\section{Narrative Authority and Authorial Persona}

Haywood's construction of narrative authority in this pair of novels in particular, and of her authorial persona in general, are essential to Haywood's ability to imbue her amatory fiction with elements of didacticism. For example, Haywood dedicated The Fatal Secret (1724), ${ }^{18}$ a novel published a year prior to the publication of The Unequal Conflict and Fatal Fondness, to William Yonge, ${ }^{19}$ one of the lord commissioners of his Majesty's treasury; she adopts a deprecatory tone about her gender, education, and subject-matter, but she also establishes an authority over her subject: Love. She writes:

But as I am a woman, and consequently deprived of those advantages of education which the other sex enjoy, I cannot so flatter my desires, as to imagine it is in my power to soar to any subject higher than that which nature is not negligent to teach us. (iv)

which we can begin to take the long view of her career and recognize that she sustained a set of preoccupations and strategies over the course of nearly forty years as a professional writer" (Juliette Merritt, Beyond Spectacle Eliza Haywood's Female Spectators. (Toronto: U of Toronto P, 2004) 5.

18 Eliza Haywood, The Fatal Secret; Or, Constancy in Distress. 3rd edition. (London: Bettesworth and Hitch, 1732.)

19 Yonge divorced his first wife in 1724 on the grounds that she had committed adultery (Oxford Dictionary of National Biography 15 May 15 2008. <http://www. oxforddnb.com.cyber.usask.ca/view/article/30232> 
She continues to explain that to write about love "requires no aids of learning, no general conversation, no application; a shady grove and a purling stream are all things that's necessary to give us an idea of the tender passion" (iv). John Richetti posits that "[d]isparagement like this of mere amatory fiction and the accompanying outline of female limitation are conventional enough, but Haywood's self-deprecation is tinged with irony, and, under all the dedicatory flattery, not a little defiance of the male world of power" ${ }^{20}$ But by positioning herself in this way, Haywood creates an authority under the guise of writing solely about love, while her texts explore not only the emotional effects of love, but also the social limitations and expectations women encountered when they attempted to pursue love or take any actions that were not sanctioned by their social system.

In The Unequal Conflict and Fatal Fondness, Haywood's narrator warns readers about the incompatibility of love and the social codes young women are expected to follow; the narrator teaches the reader that the incompatibility of love and social propriety leads to social downfalls for young women. Both novels start with a substantial amount of text dedicated to the topic. Haywood begins The Unequal Conflict by addressing the reader:

How little are those, free from passion themselves, capable of judging the effects of it on others. - How unjust is it for a person to be an umpire in a case to which he is wholly a stranger? Yet, as if severity were not a fault, at least, equally unpardonable with some it censures, people seem to take both pride and pleasure in condemning; and imagine it magnifies their own conduct to render conspicuous the errors of their neighbours. $(4)^{21}$

Immediately, the narrator calls attention to the harsh public judgment that awaits people who stray from socially sanctioned conduct and the unforgiving attitude society has towards social foibles committed for the sake of love. The narrator goes on to explain that "Love, tho' the softest and most natural of all the passions, is treated with as lit-

20 John Richetti, The English Novel in History 1700-1780. (London: Routledge, 1999) 39

21 This address to the reader in 1725's The Unequal Conflict is similar in tone to the opening of 1751's The History of Miss Betsy Thoughtless, in which the narrator states, "It was always my opinion...that those mistakes the sex [women] are sometimes guilty of proceed, for the most part, rather from inadvertency, than from inclination....There are some who behold, with indignation and contempt, those errors in others, which, unhappily they are every day falling into themselves" The History of Miss Betsy Thoughtless, volume 1. $1^{\text {st }}$ edition. (London: T. Fowler, 1752) 2-3. 
tle mercy, as those most pernicious; especially when the force of it is exerted in a female breast" (4). The social and cultural world which her heroines inhabit is hostile to women's experience of love or passion; love, and social respectability, are two separate, and often opposing, systems. The narrator calls attention to society's treatment of "the fallen fair" (4); women who transgress socially sanctioned conduct are "turn'd out, and made an alien to the family, whose ornament she was once thought. - she becomes the object of hate to the pretended virtuous of her own sex, and of contempt to the other" (5). The consequences of allowing passionate emotion to dictate one's behaviour, without consideration or awareness of one's restrictive social environment, are severe. Haywood's narrator tells the reader:

The persons, whose adventures furnish me with the subject for the following passages, were possess'd of many virtues, which ill nature of the world is willing to bury in oblivion, while one miscarriage in life swells the whole voice of fame, and will ever be flagrant, at least, till their names are no more remembered; so darling a theme is scandal and so prevailing malice. (6)

Haywood stresses that "one miscarriage" has the power to derail a person's entire life, not only in terms of any immediate consequences of a social error, but in terms of the ever-lasting damage done to one's social character. Additionally, Haywood embraces yet critiques the "darling" theme of scandal; she is aware that her tale will be popular with readers because of their general interest in scandal literature, but also acknowledges that this interest is characteristic of a judgmental and condescending society that takes pleasure in hearing about others' misfortunes. Haywood capitalizes on this interest. She constructs a titillating tale that she knows will attract readers, but also exposes the reader's potentially uncharitable attraction to such tales. She delivers both an entertaining story and a sympathetic cautionary tale about people "possess'd of many virtues" but who have fallen as a result of social mistakes. Haywood humanizes her characters and illustrates the susceptibility of even "good" people to be sidelined by poor social choices. This assertion further supports the novels' illustration of the importance of women's awareness and understanding of their social environment.

Overall, Haywood creates a sense of immediacy and applicability through these hybrid amatory-didactic tales that the formal, admonishing tone of conduct literature does not achieve. Haywood explores the precepts of conduct manuals in a context that acknowledges women's emotional and sexual desires; this acknowledgement at once recognizes women as active, feeling, desiring subjects, and draws attention 


\section{Holly Luhning}

to the necessity for women to be educated about the social systems that both define and limit them. Haywood modifies conduct manual didacticism; instead of dictating that women should blindly follow set codes of behaviour, she not only exposes the unfair rigidity of women's social roles, but also advocates that women should have an understanding of and active role in managing their social conduct.

\section{HOLLY LUHNING}

McGill University 